\title{
Towards Reviewing an Immediate Impact of COVID-19 on the Integrative World Economy: An Evolving Perspective
}

\author{
Bhavya Alankar, Jamia Hamdard, New Delhi, India \\ Harleen Kaur, Jamia Hamdard, New Delhi, India \\ Shafqatul Ahsaan, Jamia Hamdard, New Delhi, India \\ Gaurav Sharma, Jamia Hamdard, New Delhi, India \\ Victor Chang, Aston University, Birmingham, UK \\ iD https://orcid.org/0000-0002-8012-5852
}

\begin{abstract}
On 31 December 2019, WHO received inputs of pneumonia cases in Wuhan city of China, but the cause of infection could not be known initially. However, after some time, the medical researchers of China disclosed a novel coronavirus as the cause on 7 January 2020, named "2019-nCoV." The coronavirus (CoV) belongs to Severe Acute Respiratory Syndrome (SARS) species that leads to infection, causing illness, which ranges from the common cold to serious sickness. Finally, on 11 March 2020, the WHO Director-General Dr. Tedros Adhanom Ghebreyesus announced the outbreak as a pandemic. As the fear and ambiguity rose among companies and firms, the profit rate seemed to be lower due to the COVID-19 global impact. Nearly US\$6 trillion in wealth from 24th to 28 February 2020 of the stock market has been wiped out. There was a great decrease in value over the $\mathrm{S} \& \mathrm{P}$ index, which abolished over $\$ 5$ trillion in the same week. However, the largest 10 companies of S\&P faced a loss of $\$ 1.4$ trillion. The investors make an analytical prediction that firms' profits may drop in response to the impact of coronavirus. The prime focus is on the importance of digital business practices and how different sectors have been affected in terms of economic loss during this pandemic outbreak in this paper.
\end{abstract}

\section{KEYWORDS}

Coronavirus (CoV), COVID-19, Outbreak, Severe Acute Respiratory Syndrome (SARS), World Health Organization (WHO)

\section{INTRODUCTION}

The world had faced a wide range of pandemic in a different era. Medical researchers and scientists have provided different meanings to the pandemic; however, instead of different definitions of the word "pandemic" everyone agrees on, it is the outspread situation of a disease that suddenly and engulfs a geographical region such as a country or whole world. Some of the diseases like cholera,

DOI: 10.4018/JGIM.20220701.oa6

This article published as an Open Access article distributed under the terms of the Creative Commons Attribution License (http://creativecommons.org/licenses/by/4.0/) which permits unrestricted use, distribution, and production in any medium, provided the author of the original work and original publication source are properly credited. 
bubonic plague, smallpox, and influenza are declared pandemic and are the major killers in history. The smallpox disease has killed over 300-500 million people worldwide in its 12,000-year existence. The unending COVID-19 pandemic is one of the major crises of modern times. It was 11 March 2020, when the World Health Organization (WHO) declared that there is one more pandemic threat to humanity called Covid-19. With the appearance of Covid-19, all the countries are found in a "coma" like situation. Covid-19 has its roots in Wuhan city of China. On 31 December 2019, WHO received inputs of pneumonia cases in Wuhan city of China, but the cause of infection could not be known initially. However, after some time, the medical researchers of China disclosed a novel coronavirus as the cause on 7 January 2020, and were named "2019-nCoV". The coronavirus (CoV) belongs to Severe Acute Respiratory Syndrome (SARS) species that lead to infection, causing illness, starting from common cold to some serious sickness. The novel coronavirus is a new strain that has not been found in humans. The new disease was named COVID-19. As time passed, the number of cases for Covid-19 infection was increasing outside China and the condition seemed to be out of control irrespective of taking the precautions given by the World Health Organization. Finally, on 11 March 2020, the WHO Director-General Dr. Tedros Adhanom Ghebreyesus announced the outbreak as a pandemic (WHO, 2020). As the fear and ambiguity rose among companies and firms, the profit rate seemed to be lower due to the impact of Covid-19. The stock market has been wiped out nearly US $\$ 6$ trillion in wealth from $24^{\text {th }}$ to 28 February. There was a great decrease in value over the S\&P index, which abolished over $\$ 5$ trillion in the same week; however, the largest 10 companies of S\&P faced a loss of $\$ 1.4$ trillion (Jagannathan et al., 2013). The investors make an analytical prediction that firms' profits may drop in response to the impact of coronavirus.

The financial outlook of the International Air Transport Association (IATA) in 2020, showing the global air transport industry with a net profit margin of -20.1 percent, lose $\$ 84.3$ billion. Revenue will drastically fall in 2019 from 50\% to $\$ 419$ billion from $\$ 838$ billion. In 2021 , as revenue rises to $\$ 598$ billion, losses are expected to be cut to $\$ 15.8$ billion (Jagannathan et al., 2013). The flight and hotel bookings were canceled on a large scale, the cancellation of local and international events worth $\$ 200$ billion. The flow of goods across the countries cut down extensively. The Chinese government declared the shutdown of main factories in the country, as China is one of the worlds' largest producer and a broker. The government of many countries like Iran, Italy, France, and India framed 'stay-athome' and 'social distancing' policies to manage the spread of coronavirus as it had taken millions of lives. The implementation of 'stay-at-home' like policies sow the seeds to decrease business activities in most developed countries. The economists agreed that this deadly virus pandemic would push the world into a global recession.

The literature over the grounds of recession is vast (Stiglitz, 2010; Gaiotti, 2013; Bezemer, 2011; Mian and Sufi, 2010; Bentolila et al., 2018; Bagliano and Morana, 2012; Radelet et al., 1998_. However, the collapse in business activities for the year 2020 was novel in history. The recession due to coronavirus is different from the past. For example, in 1997, the fall down of the Thai currency in July 1997 generated fear that leads to region-wide monetary calamity and economic recession in Asia (Allen and Carletti, 2010). In 2008, a recession in terms of financial crisis occurred due to monetary policy followed by mortgages and their strong influence in the banking sector (Lu, 2020). In Nigeria, the drop in the price of crude oil, an increase in the pump price of petrol in 2016 took the shape of the recession.

\section{Background}

Many theories are in the air that how did this Coronavirus spread. A section of the people believes that this has been transmitted from the pigs, while another section believes that the Bats are the root cause. Some scientists came with the theory that China intentionally made this virus in its Wuhan lab. It is seen as a counter-strategy against the USA. Even microbiologists and genetic experts believe that this virus has been changing its basic form very speedily, making it more dangerous to control. The traveling, trade and large-scale gatherings made the situation worse and worse. First world countries 
suffered first of all due to their high level of global involvement, and then it spread to Asia, Southeast Asia, Oceania, and the poles.

On 31 December 2019, the China health authority alarmed the World Health Organization (WHO) about some cases of pneumonia due to some unknown source in Wuhan city in Hubei Province in central China. However, the cases had been reported since 8 December 2019, and some of the infected persons are supposed to be working at or living around the Huanan seafood wholesale market, but other patients had no links with this market (Hui, 2020). On 7 January 2019, a novel coronavirus was diagnosed from the throat swab sample of a patient (Gorbalenya, 2020). The virus that proved to be the root was renamed Severe Acute Respiratory Syndrome (SARS) coronavirus 2 (SARS-CoV-2) by the Coronavirus Study Group (Burki, 2020) and this disease was named coronavirus 2019 (COVID-2019) by the WHO. At the initial stage in January 2019, it was reported that 30, 7736 persons' are infected and 12,167 suspected cases had been diagnosed in China and 82 other cases were confirmed in other countries of the world (Harapan, 2020). The WHO alarmed all the countries about this deadly virus and declared the SARS-CoV-2 outbreak as a Public Health Emergency of International Concern (PHEIC) (Harapan et al., (2020). As per the reports of the National Health Commission of China, in the first week of February, the death rate of confirmed cases was $2.1 \%$. According to the CDC Morbidity and Mortality Weekly Report(2020) and outside China, it was 0.2\% (Huang, 2020). The mortality rate for the patients admitted to hospitals was $11 \%$ to $15 \%$ (Chen et al., 2020; Horowit, 2020). After that, coronavirus infection spread like a forest fire that was indicating no signs to be controlled with a relatively high mortality rate.

The COVID-19 epidemic has disturbed the economy of China and is spanning worldwide. The trends and economic effects of this disease are extremely unpredictable, making it difficult for politicians to establish an adequate response to macroeconomic policy (El-Erian, 2020; García-Vidal et al., 2020). Today, there is an on-going crisis triggered by the coronavirus disease 2019, a global pandemic that has rocked our economic and social balance. We have created a new set of standards for our behavior, both personal and social habits (El-Erian, 2020). (Bagliano and Morana, 2012) as COVID-19 hit company downs, the economy was significantly affected. The effect of economic downs caused by closed businesses by social distance policies led to the lack of operating structures for many small businesses and a reduction in profit and sales (Lechman and Kaur, 2016; Marszk et al., 2017). A record of 22 million workers suffered unemployment because of company losses. The outbreak of COVID-19 has also altered the behavior of people and changed the way how people are doing business. Because more customers shop online in busy stores to escape unsafe circumstances, small retailers suffer profits and customer losses. Digital innovations and new Government policies are the need of the hour to recover small-scale enterprises from economic instability as well as to reopen their capacity to become more robust and efficient. Thus Digital business has a huge capability to drive the economy of a country to prosperity.

\section{SPREAD OF COVID-19}

The real-time data on the spread of covid-19 has been collected from worldometer. The statistics in table 1 represents the figures till 18 October, 2020, for the most affected 20 countries of the world where they us has the highest number of cases followed by India, Brazil, Russia, and Spain. Table 1 showed the statistical figures of covid-19 affected countries population and statistics includes the total number of cases, recovered, deaths, and population count. As of $18^{\text {th }}$ October 2020, statistics showed how much this pandemic impacts the countries.

On 5 October 2020, WHO issued the updated situation report and represented that over 2.2 million new cases and 39,000 deaths due to COVID-19 are shown in fig 1 and 2. In a single week from 30 December 2019 through 11 October 2020, the highest number of COVID-19 cases is reported (Bagliano and Morana, 2012). In the USA, Brazil and Argentina region, the number of deaths and new cases reported each day and set a global record in Table 2 . Table 2 showed the percentage number of 
Table 1. Caption COVID-19 statistics (as on $18^{\text {th }}$ October 2020)

\begin{tabular}{|c|c|c|c|c|c|c|}
\hline S. No. & Country & Total Cases & Total Deaths & $\begin{array}{l}\text { Total } \\
\text { Recovered }\end{array}$ & Active Cases & Population \\
\hline & World & $40,023,720$ & $1,115,601$ & $29,935,273$ & $8,972,846$ & \\
\hline 1 & USA & $8,343,244$ & 224,284 & $5,432,457$ & $2,686,503$ & $331,579,250$ \\
\hline 2 & India & $7,494,551$ & 114,064 & $6,597,209$ & 783,278 & $1,384,011,899$ \\
\hline 3 & Brazil & $5,224,362$ & 153,690 & $4,635,315$ & 435,357 & $213,007,476$ \\
\hline 4 & Russia & $1,399,334$ & 24,187 & $1,070,576$ & 304,571 & $145,953,192$ \\
\hline 5 & Spain & 982,723 & 33,775 & N/A & N/A & $46,760,199$ \\
\hline 6 & Argentina & 979,119 & 26,107 & 791,174 & 161,838 & $45,318,390$ \\
\hline 7 & Colombia & 952,371 & 28,803 & 847,467 & 76,101 & $51,042,890$ \\
\hline 8 & France & 867,197 & 33,392 & 104,696 & 729,109 & $65,316,637$ \\
\hline 9 & Peru & 865,549 & 33,702 & 774,356 & 57,491 & $33,106,697$ \\
\hline 10 & Mexico & 847,108 & 86,059 & 615,680 & 145,369 & $129,332,476$ \\
\hline 11 & UK & 705,428 & 43,579 & N/A & N/A & $67,992,038$ \\
\hline 12 & $\begin{array}{l}\text { South } \\
\text { Africa }\end{array}$ & 702,131 & 18,408 & 630,436 & 53,287 & $59,528,656$ \\
\hline 13 & Iran & 530,380 & 30,375 & 427,400 & 72,605 & $84,309,106$ \\
\hline 14 & Chile & 490,003 & 13,588 & 462,712 & 13,703 & $19,164,757$ \\
\hline 15 & Iraq & 423,524 & 10,198 & 357,291 & 56,035 & $40,484,014$ \\
\hline 16 & Italy & 402,536 & 36,474 & 249,127 & 116,935 & $60,435,147$ \\
\hline 17 & Bangladesh & 388,569 & 5,660 & 303,972 & 78,937 & $165,173,926$ \\
\hline 18 & Indonesia & 361,867 & 12,511 & 285,324 & 64,032 & $274,377,003$ \\
\hline 19 & Germany & 361,733 & 9,853 & 290,000 & 61,880 & $83,863,824$ \\
\hline 20 & Philippines & 356,618 & 6,652 & 310,158 & 39,808 & $110,009,666$ \\
\hline
\end{tabular}

(source: Worldometer)

increase and decrease in covid-19 new cases and death cases. As per WHO weekly statistics, Figure 1 and Figure 2 show graphical representation, how covid-19 globally affects the life of the persons, and how much this pandemic is life-threatening.

\section{GLOBAL IMPACT OF COVID-19 OUTBREAK}

The perception made initially about the COVID-19 pandemic is that it would only be localized in China. However, traveling from China to the outside world was the main source of spreading this disease throughout the globe. Within almost two months, the wave of COVID-19 reached every corner of the world. The governments of the respective countries framed policies like "Stay Home Stay Safe" to prevent coronavirus spread. The beginning in the fall of the economy was an alarming situation as the citizens are asked to stay at home, and the severity was experienced in multiple sectors of the economy with a ban on flights affecting the aviation industry, the sports industry was disturbed due to cancellation of sports events, the restrictions on mass gathering of people make a huge loss to the event organizers and entertainment industry. 
Figure 1. Weekly reported cases and global deaths due to COVID-19 from 30 December 2019 through 11 October 2020 by WHO

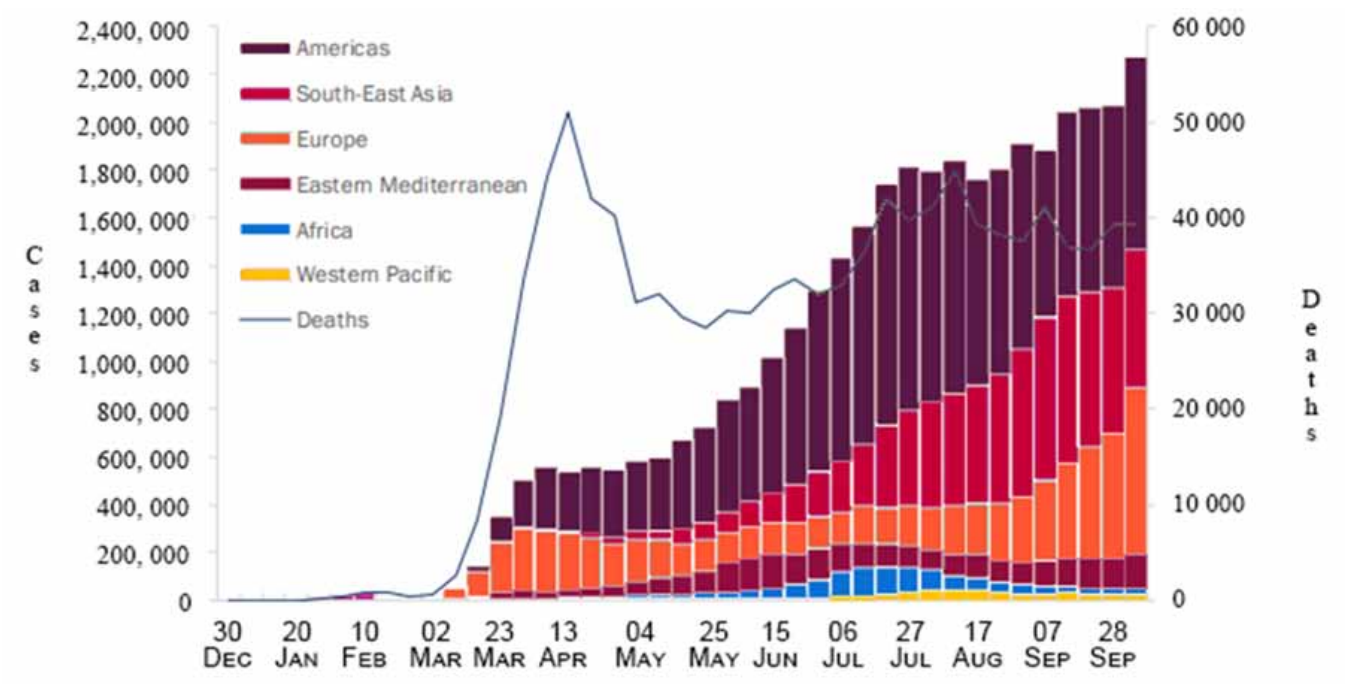

\section{Week Reported}

Epidemics distributed over a broad international geographical area have been reported. It plagues a great part of the world's population and creates substantial historical disparities because of social and environmental shifts. Hui et al. (2020) Several pandemics have been recorded worldwide, including Ebola, Pest, Flu and today COVID 19 or SARS -COV 2. Corona Virus ID 19 or COVID 19 is a Serious Acute SARS virus mutation that occurred in Chinese territory in 2003. It is a human-

Figure 2. Reported cases and global deaths due to COVID-19 from 30 December 2019 through 11 October 2020 by WHO

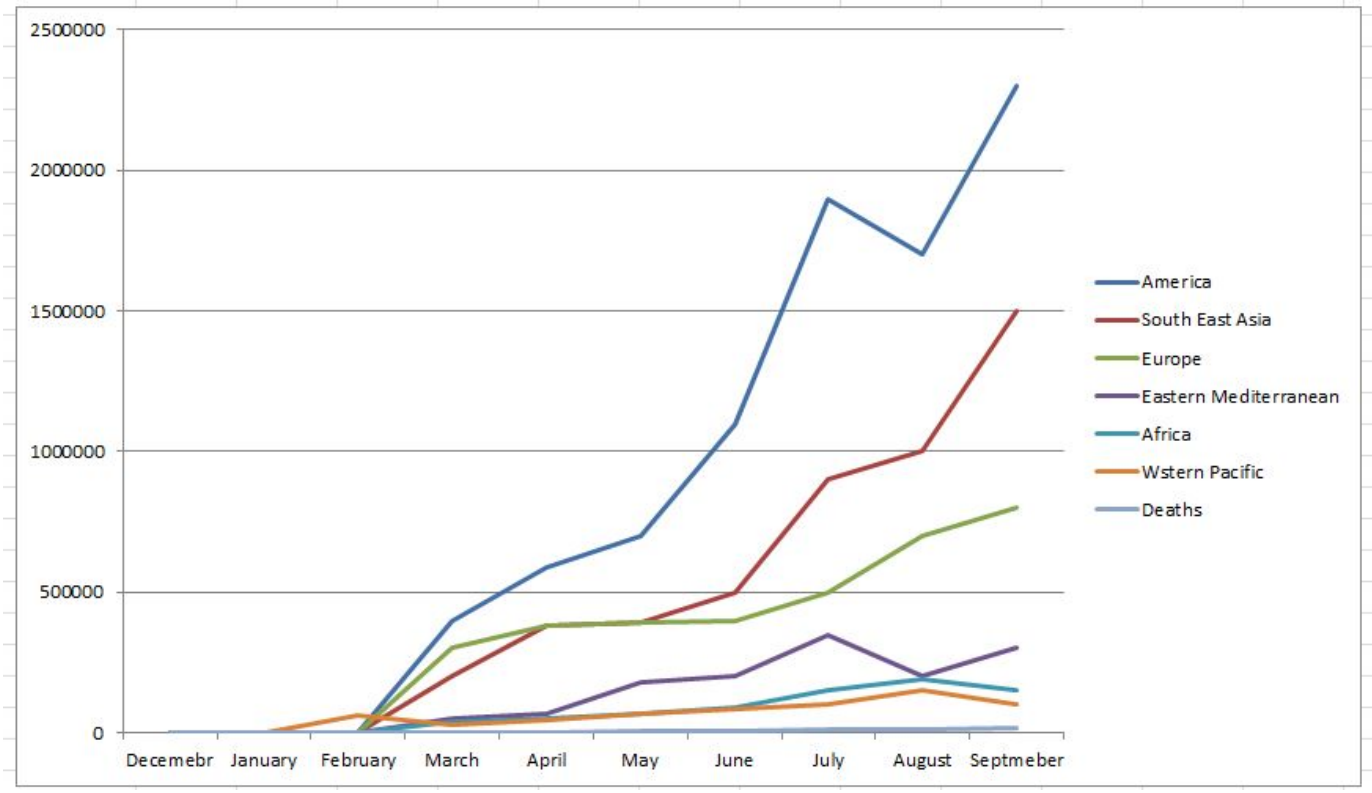


Table 2. New cases, confirmed cases and deaths in COVID-19 reported by WHO Region, as of 11 October 2020

\begin{tabular}{|c|c|c|c|c|c|c|}
\hline WHO Region & $\begin{array}{l}\text { New Cases } \\
\text { in Last } 7 \\
\text { Days }(\%)\end{array}$ & $\begin{array}{l}\text { Change in } \\
\text { New Cases in } \\
\text { Last } 7 \text { days }\end{array}$ & $\begin{array}{l}\text { Cumulative } \\
\text { Cases (\%) }\end{array}$ & $\begin{array}{l}\text { New Deaths in } \\
\text { Last } 7 \text { days (\%) }\end{array}$ & $\begin{array}{l}\text { Change in New } \\
\text { Deaths in Last } \\
7 \text { Days* }\end{array}$ & $\begin{array}{l}\text { Cumulative } \\
\text { Deaths (\%) }\end{array}$ \\
\hline Americas & $\begin{array}{l}804735 \\
(35 \%)\end{array}$ & $6 \%$ & $\begin{array}{l}17794771 \\
(48 \%)\end{array}$ & $\begin{array}{l}20509 \\
(52 \%)\end{array}$ & $-5 \%$ & $\begin{array}{l}588867 \\
(55 \%)\end{array}$ \\
\hline $\begin{array}{l}\text { South-East } \\
\text { Asia }\end{array}$ & $\begin{array}{l}575763 \\
(25 \%)\end{array}$ & $-6 \%$ & $\begin{array}{l}7911036 \\
(21 \%)\end{array}$ & $\begin{array}{l}7750 \\
(20 \%)\end{array}$ & $-8 \%$ & $\begin{array}{l}126917 \\
(12 \%)\end{array}$ \\
\hline Europe & $\begin{array}{l}694275 \\
(31 \%)\end{array}$ & $34 \%$ & $\begin{array}{l}6918265 \\
(19 \%)\end{array}$ & $\begin{array}{l}6172 \\
(16 \%)\end{array}$ & $16 \%$ & $\begin{array}{l}246709 \\
(23 \%)\end{array}$ \\
\hline $\begin{array}{l}\text { Eastern } \\
\text { Mediterranean }\end{array}$ & $\begin{array}{l}138751 \\
(6 \%)\end{array}$ & $10 \%$ & $\begin{array}{l}2605478 \\
(7 \%)\end{array}$ & $\begin{array}{l}3173 \\
(8 \%)\end{array}$ & $13 \%$ & $\begin{array}{l}66329 \\
(6 \%)\end{array}$ \\
\hline Africa & $\begin{array}{l}29169 \\
(1 \%)\end{array}$ & $11 \%$ & $\begin{array}{l}1227719 \\
(3 \%)\end{array}$ & $\begin{array}{l}991 \\
(3 \%)\end{array}$ & $27 \%$ & $\begin{array}{l}27255 \\
(3 \%)\end{array}$ \\
\hline $\begin{array}{l}\text { Western } \\
\text { Pacific }\end{array}$ & $\begin{array}{l}26199 \\
(1 \%)\end{array}$ & $6 \%$ & $\begin{array}{l}651841 \\
(2 \%)\end{array}$ & $\begin{array}{l}633 \\
(2 \%)\end{array}$ & $26 \%$ & $\begin{array}{l}14265 \\
(1 \%)\end{array}$ \\
\hline * Other & - & - & $\begin{array}{l}741 \\
(<\%)\end{array}$ & - & - & $\begin{array}{l}13 \\
(<1 \%)\end{array}$ \\
\hline Global & $\begin{array}{l}2268892 \\
(100 \%)\end{array}$ & $10 \%$ & $\begin{array}{l}37109851 \\
(100 \%)\end{array}$ & $\begin{array}{l}39228 \\
(100 \%)\end{array}$ & $<1 \%$ & $\begin{array}{l}1070355 \\
(100 \%)\end{array}$ \\
\hline
\end{tabular}

communicable virus that essentially targets the human respiratory system, leading to air problems that can lead to the death of the patient affected in some severe cases. The danger and the possibility of the pandemic are persistent in a globally changing environment experiencing significant climate change and is increasingly globalized and open (Qiu, et al. 2020).

The worldwide economy has been extremely impacted by a rapidly growing mortal Covid- 19 . As a result, billions have been struck in the top 15 countries in the world, including India. According to a United Nations study, trades in India may have an effect of some \$348 million on the Covid-19. China is the most affected by Covid-19, the study states. China is the most affected. World exports from China could be cut to 50 billion dollars. Machinery, industrial and communication devices are industries most affected by Covid-19. Among the most impacted economies worldwide are the European Union, which has been the worst impacted (15.6 billion dollars), the USA (5.8 billion dollars), Japan (5.2 billion dollars), and South Korea, China, and Vietnam (2.3 billion dollars), the OCDE.

Covid-19 would have a major effect on the emerging economy of Asia, the Asian Development Bank has reported. According to CII, $43 \%$ of India's top 20 products are imported from China. This covers 7.2 billion dollars cell handsets, 3 billion dollars machines and components, and 1.5 billion dollars in fertilizer imports. Because of the serious effect of Covid-19 on the Chinese economy, this would have a large impact on India.

\subsection{Impact on Travel Industry}

The coronavirus outbreak forced the governments of various countries to place limitations on unnecessary travel to the COVID-19 affected countries. It suspended the services of tourism, visas like work visas, and immigrant visas. Some countries lay down a complete ban on any kind of inward or outward travel because of the pandemic and ceased all airports in the country. At the peak of the coronavirus pandemic, a good number of airlines operate without passengers as the flow of passengers lessens as a result of mass passenger cancellations. The restrictions put by the government on any type of movement caused demand drop on all forms of travel, which forced some airlines to suspend their operations to airlines such as LOT Polish Airlines, Air Baltic, Scandinavian Airlines and La 
Compagnie. The imposition of such travel limitations cost the tourism industry a loss of more than US $\$ 910$ billion to US $\$ 1.2$ trillion. Besides, 100 to 120 million jobs are at risk. The International Air Transport Association (IATA) released its financial outlook for the global air transport industry, showing airlines are expected to lose $\$ 84.3$ billion in 2020 for a net profit margin of $-20.1 \%$. Revenues will fall $50 \%$ to $\$ 419$ billion from $\$ 838$ billion in 2019. In 2021, losses are expected to be cut to $\$ 15.8$ billion, as revenues rise to $\$ 598$ billion (Jagannathan et al., 2013). The available data indicates a $22 \%$ decline in the first quarter of 2020, with incoming data declined by $57 \%$ in March. This means losses of 67 million foreign arrivals and revenues of some USD 80 billion according to (UNWTO, 2020). In 2020, financially, it is the worst year in the aviation sector, which losses $\$ 230$ million and 2.2 billion passengers due to the COVID-19 pandemic.

The travel industry has been severely affected by the Covid-19 pandemic. Worldwide polls, reports on its adverse impact on the world's biggest financial prudence have been published. Even experts in many sectors say the Covid-19 is an obstacle. In the United Nations World Tourism Day report, tourism employment in many Asian and European countries had dropped by more than 25 percent. Some studies have shown that employment and explorations in the tourism sector have decreased by about $40 \%$. The UN said the stint is now on the tourism sector's future to be rethought. It must also see how this sector will contribute to achieving sustainable development objectives through its social, cultural, political, and economic values. Six rankings in the travel sector have jumped India at the same time. The outbreak of Covid-19 broke the travel industry. The travel industry finds it difficult to get up.

\subsection{Impact on Hospitality Industry}

The coronavirus wreaks a severe relentless economic crash over the hospitality industry than the 11 September 2001 terrorist attack and led to a great recession in the hotel industry. The "stay-at-home" and "social distancing" policies by the government put bounds on the movement of people that mainly affected the restaurant business. The hotels and restaurants in the cities and towns are being closed temporarily for a limited period as per the government orders to control the spread of COVID-19. The sudden closure of hotels and restaurants shocked the hotel owners because hotels worldwide observed a mass booking cancelation worth millions of dollars and the hotel industry required $\$ 150$ assistance. The Hospitality Sector links or provides businesses to small sectors such as travel agencies, local markets, street salespeople, drivers, and others. However, these small sectors are often impacted by the recession in their everyday operations due to this pandemic. As the lockdown has shut down all tourism platforms, travel tickets are canceled and hotel reservations are not reserved and hotel reservations slow down or completely shut down the hospitality sector's revenue. The hotel industry could lose 4 million jobs due to the impact of coronavirus. The restaurant executives discharged their staff as they quit their operations temporarily. People prefer to eat at home rather than in restaurants because of the coronavirus threat. Some business enterprises rejected the policies of "stay-at-home" and "social distancing" that shattered small business outlets, as the hotel industry lost more than $\$ 46$ billion in room revenue. The current room occupancy rate is predicted to lose nearly $\$ 400$ million in room revenue per day. The Bureau of Labor Statistics reported the hospitality sector had lost 4.8 million due to the pandemic (AHLA, 2020).

\subsection{Impact of COVID-19 outbreak on Oil-dependent Countries}

\subsubsection{Oil Price War}

At the beginning of 2020, a drop in oil prices was witnessed because of the oil price war between Russia and Saudi Arabia. The situation was still out of hand, and it worsened further due to the outbreak of coronavirus in terms of minimum demand for oil. The government imposed restrictions which act as a barrier in the movement of people and goods, the market value for air-fuel, coal, and other commodity decreased as a result of low oil demand. The travel restrictions placed by the government act as a barrier in the movement of people and goods. The market value for air-fuel, coal, 
and other commodities decreased due to low demands for oil. The impact of coronavirus was seen over bio-fuel and energy renewable markets. It restricted the movement of people, which directly influenced the dire downturn in demand for transportation fuels. At the time of the pandemic, the market was flooded with too much oil. However, the demand was very low and consequently resulted in a drop in oil price.

\subsubsection{Loss in Oil Revenue}

The oil-producing countries hit the most in the pandemic. The demand for oil products was very low in the international market, resulting in a decent drop in oil prices that led to a considerable deficit in oil revenue to the countries that depend on oil resources. The downfall in the oil prices led to the decline of local currencies versus the dollar of these countries, like over their foreign exchange reserves Kenya, Nigeria, and South Africa. The national budgets of such countries were also affected. The continuous devaluation in global oil prices in oil-producing countries as a result of the COVID-19 pandemic indicated that the national budget had outdated and required to be amended. The national budget set before the pandemic did not catch the present economic reality. Therefore, the national budget of some oil-producing countries seemed to be in deficit, which forced some countries to either (i) ask for a loan from IMF, World Bank, and other banks so that the budget shortfalls may be filled or (ii) frame a new national budget plan keep in view the current situation in the international oil market.

\subsection{Impact on the Financial Sector}

The macroeconomic falloff resulted in a rise to nonperforming loans in the banking sector by 250 basis points. During the outbreak, private banks are at high credit risk. The loans that are being issued to small and medium scale enterprises, airlines, restaurants, hotels, and tour operators led to nonperforming loans. There was a quite decrease in the number of bank transactions, a decline in the payments carried out by credit cards and a drop in the use of ATMs globally. Hence, the charges imposed by banks while using these services were quite low, which influence the profit collected by banks. During the pandemic, not only did banks face a loss of profit, but FinTech businesses experienced very low investment by clients that resulted in a loss of revenue and profits. Due to the loss of FinTech companies, a negative impact was witnessed on the capital investment that funded existing and new firms.

Due to the lockdown worldwide due to Covid-19, the bank and financial sector are also anguish dense losses. One, the new loan is entirely sealed due to lockdown. In the same period, the collection has also been reduced from the 3-month to 5-month moratorium. The retail and SME sector also faces a big impact. Recently, there was anticipation from the government about the banking sector from recapitalization, but the lockdown also ruined these anticipations. In the lockdown, measures by the RBI to upsurge liquidity are also not enough. In such a state, the concert of the banking sector is going to be poor for the fourth quarter, while the next coming two quarters also have the effect of lockdown on the sector.

At present, the NPA of banks is anticipated for additional upsurge due to its slowdown in corporate purpose. In such a state, the strength excellence of banks will be exaggerated. The financial sector has to endure the impact of the delay in repayment and loan growth coming down to lower levels due to the moratorium in lockdown. On the other side, other private sector banks, their financial enactment was strong till the lockdown. Banks were benefiting from healthy credit growth, increased net interest margin, and a strong cash base. But the lockdown worsened the situation. The way the fear of recession has increased due to Covid-19 also impacts the banking sector. This will have the correct effect in the first quarter of the current financial year. But banks may increase provisioning for the March quarter. 


\subsection{Impact on Financial Global Markets}

The effect on the global stock market was the most noticeable reaction of the COVID-19 financial market crisis. According to S\&P Dow Jones Indices, the global financial markets lost $\$ 6$ trillion within six days from 23 to 28 February 2020 . The S\&P 500 index drastically decreased by $28 \%$ (from 3,373 to 2,409), the Nikkei dropped by $29 \%$ (23,479 to 16, 52), and the FTSE 250 index decreased by $41.3 \%$ (from 21,866 to 12,830 ). The international banks, during the same period, experienced a quick drop in their share price such as JP Morgan's share value dropped by $38 \%$ (from US $\$ 137.49$ to US\$85.30), Barclay's share price declined by 52\% (from $£ 181.32$ to $£ 86.45$ ), and Citigroup's share price dropped by 49\%(from US\$78.22 to US\$39.64) Radelet et al. (1998). At the beginning of 2020, a drop in oil prices was witnessed because of the oil price war between Russia and Saudi Arabia. These countries were competing to drop the oil price by increasing oil production, which played a key role in the plunge in stock market indices. Another reason for the drop in stock market indices in March was investors' departure towards safety, keeping in view the COVID-19 pandemic.

Some industries are highly affected by this pandemic, like the Tour and Travel industry, Retail Companies, and hospitals, etc. In many countries, the travel and tourism businesses fall down around $85 \%$ to $95 \%$. The latest estimates show that international tourist arrivals in the first half of 2020 have dropped 65\%. The World Tourism Organization predicts international tourism revenue to fall between $\$ 910$ billion and $\$ 1.2$ trillion this year (i.e., international tourism expenses). Therefore, the world's tourism industry will be back 20 years (UNWTO, 2020). According to the study, the pandemic directly damages foreign direct investment, and global foreign direct investment falls almost $40 \%$ in 2020 and the effect of this fall down shows on global production and supply chains.

\subsection{Impact on the Health Sector}

Due to the very high spreading rate of Covid-19, the pandemic globally spraining the healthcare sector. The Healthcare sector is the most appearance worldwide pandemic challenge. With the increased demand for medical facilities, medical emergency services are overstretched. Due to this increase in medical services, healthcare sectors are unable to run or deal with the situation effectively. Globally governments are dealing with and responding to this pandemic differently, like total lockdown. People have been instructed to "Stay at home", maintain the social distancing, and other measuring precautions. Private healthcare has risen in support of governments by offering, testing support, organizing isolation beds for Covid-19 patients, or deploying medical infrastructure and more medical staff in healthcare sectors. To deal with the pandemic, it needs a strong medical infrastructure. But unfortunately, maximum countries have been failed and Covid-19 has exposed to developed countries.

With the outbreak of COVID-19, the flow of patients in government hospitals has increased and there was a high demand for services, but the testing facilities for coronavirus were abundant in private hospitals. As the number of cases seemed to be increased, the China government shut down all the hospitals in Wuhan city. The hospitals in Iran move violently to deal with the coronavirus outbreak. The Spanish government declared a national emergency because of the spreading of the virus swiftly. As the number of COVID-19 patients was increasing at a pace, the Singapore government took a bold step in managing patients from other countries. Singapore had adequate healthcare facilities and workers to deal with this deadly viral disease.

The outbreak of coronavirus affected the pharmaceutical supply chain extensively. The factories of China are the major suppliers of Active Pharmaceutical Ingredients (API). Drug-makers all around the globe are heavily dependent on these factories. About $60 \%$ of API were manufactured in China before the existence of coronavirus. As the coronavirus appeared in China and was at the peak, China stopped the operation of major factories, including drug-making factories. Before the coronavirus, the pharmaceutical companies did not stock adequate amounts of APIs resulted in a short supply of some essential drugs. However, those medical companies with a full stock of APIs are not ready to sell them in fear of running out of stock, while some other companies were selling at a very high price (Sato et al., 2020). 
The health insurance companies also became the target of the COVID-19 pandemic. In the US, some health insurers are unable to manage the medical insurance dues in the hospital sector. Due to this, the impact of COVID-19 on the economy of the health sector was negative. The healthcare sector investors were extremely hit by the COVID-19 pandemic as the S\&P 500 Managed Health Care index dropped by $7 \%$ at the end of February.

As per Moody's rating agency, the outlook of nonprofit and public health care sectors was downgraded from stable to negative due to the nonstop spread of COVID-19. The statement was given by the rating agency clearly stated that the nonprofit health care companies face an increase in expenses even if the coronavirus outbreak is put under control. The bankers who have invested in health care target the medical supply firms to reflect on strategies to profit from the crisis by raising the prices. The increasing number of deaths because of insufficient drug supply, the requirement of vaccines to cure patients that are still lacking, poor accommodation in hospitals, and isolation centers for COVID-19 infected patients.

\subsection{Impact on the Education Sector}

The loom of coronavirus disturbed the $\$ 600$ billion higher education industry. After the coronavirus outbreak, the most affected countries declared a public health emergency, and the schools and colleges are instructed to suspend their routine work and the "stay-at-home" policy was followed strictly. The education sector that is influenced mostly by this disease is that not have an online learning platform for the students.

The Covid-19 majorly disrupts government schools and mid-class private schools. They could not provide education through a digital platform and shut down completely for not having found the digital learning solutions. Due to the lack of digital gadgets and money, a continuously-growing number of students has missed their e-learning and faces economic stress.

Education Sector has been the largest affected sector due to this Covid-19 pandemic in history, Approximately 1.5 billion students, teaches, and learners affect more than 200 countries. Shutdown of Universities, higher education institutions, schools d further education spaces have obstructed more than 90 percent of the world's student population, up to 99 percent affected in low, middle, and developing countries.

According to Moody's credit rating, it is very challenging to accommodate the academic and financial changes required to deal with the coronavirus outbreak in Colleges and Universities globally. As reported in the UNESCO, at least 290.5 million students are affected globally by the pandemic. Countries like Canada, the UK, and the US lost billions in education revenue because they have a high number of international students. When the restrictions were imposed on travel, a large number of students either quit their studies or looked elsewhere for a quick education. However, the significance of online teaching and remote learning is improved in the pandemic outbreak.

\subsection{Impact on the Real Estate Sector}

Of all the current economic sectors, the real estate sector is also considered a very important sector. In global immobilization, capital volumes are dropping. Reports show that the global capital in the first half of 2020 decreased by almost 29 percent or by $\$ 321$ billion compared to the previous halfyear period. According to the JLL report, complete lockdown and travel restrictions were the main cause of a decline in the real estate sector. Capital volumes decreased by almost $37 \%$ in the US real estate industry, while in Asia, capital decreased by about $32 \%$ and other regions almost $13 \%$. As a result of Covid-19, this sector will employ up to 11 million or $25 \%$ of the workloads. The Covid- 19 had the most effect on the immobilization market.

\subsection{Impact on the Sports Sector}

As a consequence of Covid-19, the improbability in the sports field is not overcome without hesitation, but it does mask the future of sports competitions. The effect of Covid-19 on the sports industry has 
already been illustrated by many major sporting events, including the Tokyo Olympic, ICC Cricket Series, Tennis, Formula One, the Monaco Grand Prix, Football Series, Hockey League, Golf League and the majority of sports leagues have either been postponed or canceled. By seeing the pandemic, many International Sports Association decide to postpone the major sports events. International Cricket Council announced that both genders of the ICC T20 World Cup had been postponed in cricket. The final Pro14 at Cardiff Stadium, which was secluded in June 2020, was cancelled in the Rugby sector. During the rest of the 2020 season, the main rugby league (MLR) was canceled. The FIH has agreed to cancel all FIH Pro League events scheduled to take place in May, June, and July in the hockey sector. All the Major Baseball League season matches in Mexico \& Puerto Rico were aborted in the baseball sector. The Snooker section has been postponed from 18 April to 4 May for the World Snooker Championship held in Sheffield. Due to Covid-19, the golf association rescheduled the LGPA tour from September to November 2020. Similarly, The Portuguese motorsport game was delayed after the Portuguese government had declared a state of emergency and had all sporting activities in Portugal suspended. The European Aquatic Championship 2020 in Hungary was expected to take place in the swimming section from 11th to 24th but has been deferred to August. The Events team, Sponsors, and the Sports Association faced the loss of revenues by billions of dollars due to the cancellation and postponement of the Sports League.

Many significant improvements in sport and player routines have already been noted. The rules of certain games have changed, as cricketers are avoided shaking hands, prohibit saliva and several other rules from preserving social distances have been enforced. Likewise, tennis won't play a dual match for a few days. The ITF has told players to carry a ball and towel and remain four to six meters away from the ball boy and match officers. Some games seem hard to start for a long time.

In the meantime, the reports show that sports employment in the area of sport has decreased by over $25 \%$. In addition, the world's quest for sports increased by $11 \%$ compared to 2019 over the last few months, enough to show the pandemic has weakened sports world mathematics. The Covid-19 allows trainers and coaches to lose their employment in a sports center, arena, gym, etc., locked during the lockdown. That is why candidates have faced more difficulties in this area.

But a positive side of this apprehension is that due to aversion to international visits, local infrastructure can be improved. Because in this situation, care must be taken to increase training facilities in the region. In the middle of the possible crises of Corona, if we look forward to this big benefit, this crucial mechanism will start to make the crisis a good one as it progresses.

\subsection{Impact on the Entertainment Sector}

During the last year, this corona pandemic impacted entertainment, media OTT platforms and the social life of the entire world. This starting took place in the last fifteen months, which is still creating havoc. The pattern in which people used to entertain themselves has been entirely changed. Now, outgoing entertainment stores, physical infrastructure as well as famous hangout corners have been deserted. This brought the need for a new phenomenon by which we can fill up this gap. Many overthe-top (OTT) platforms came forward to fill this vacuum. Amazon Prime, Netflix, HBO Now, and like are the best example of it. They provided multi-dimensional entertainment at a very affordable rate.

People globally adopted and appreciated this new technology hand in hand. This new wave overcame the challenges created by this Covid-19 pandemic. As it was a global lockdown, people had no option of going out and enjoyed the usual entertainment mediums. This sector showed a silver lining in this bleak darkness.

Persons involved with film production, editing and the like suffered a lot due to lockdown, but these platforms gave them the golden opportunity to show their content and skills globally online, resulting in minimizing their loss. Significantly the people involved at the lower level got some work to run their families. A new methodology came into play to run this whole sector even in this difficult time. Business houses invested their money in new projects with risk as well as hope. 
But the other side of the coin is that this Covid-19 stopped many movies, television, serials, short movies, commercial TV ads, etc., which resulted in the loss of employment and wages for many. They faced hardship and agony during that time, even struggled for their food. They had to change their occupation and migrate from one field to another. Countries like America, Canada, Mexico, Germany, Italy, and France had to stop earlier as the spread of covid19 was earlier compared to developing countries. This was due to the difference in their economic structure as more population in first world countries is involved in the service sector while in developing countries in manufacturing. There is no doubt that India is an exception where the majority of the population is involved in the service sector.

The mass media, print media, electronic media, etc., underwent new changes. The viewership of news channels, music channels and movie channels increased, but print media faced some reservations regarding contamination. This sector also caught growth when the apprehensions were cleared regarding their safety. A new positive trend was seen in subscription taking and recharges for these services. The viewing period also increased from an average of 2-3 hours to 6-7 hours, but this came with some health issues and eye dryness, headache, fatigue, long sleeping hours, etc.

The media persons, staff and officials working in these sectors emerged as the 'corona warriors'. They took their responsibility to cover news, gather information, data and other important issues. They put their life in danger but informed and warned people. They represented why this sector is called the fourth pillar of Democracy.

\subsection{Impact on Digital Businesses}

Social distancing and lockdown due to Covid-19 are highly responsible for the behavioral transition of the consumers and merchants as far as the trading and business are concerned. The digital mechanism of business, which was very rare and limited to large scale trading companies, is becoming crucial for the small traders and consumers. The implementation of social distancing has limited the trading behavior of small segment traders, which are considered to be the driving force for the economy of a country. However, since Corona panoramic, Small traders are more affected, as their business is mostly dependent on the cash flow of the market and physical interaction.

Various businesses that rely on physical space such as restaurants, markets, shopping malls, transportations are afflicted due to social distancing and limited reach of consumers in the physical markets. As a result, people are bound to change their trading behavior in an online mode to sustain in this adverse situation. In this pandemic like Covid-19, the use of technology is the best option to keep the stability of small merchant enterprises (Allen and Carletti (2010). Most of the small-scale enterprises are not aware of the digital transformations in the business community. For them, this is the right time to enter into digitization to sustain their business capabilities.

The digital approach will lead the small enterprises to learn alternated business practices and can, therefore, enter the post-pandemic market to survive their business practices. During these covid-19 conditions, traders can strengthen their marketing strategies online for logistics and sales. Since the consumers and traders are now becoming ready for digitization, digital skills and Govt. policies are needed to strengthen the business entities now and in the future.

Digital transformations are a must for businesses in post-pandemic recovery phases. The virtual integration of consumers, sellers and traders is the need of today's market. Reducing human interaction at various stages of trading can be a great option during this crisis. For this, the government has to make some policies to support the post-pandemic business environment. Some of the areas in which the Government and Enterprises need to be focused are enhancing Digital transaction innovations, creating a resilient infrastructure for IT applications, and building a technology-centered entrepreneurial ecosystem. 


\section{POLICY MAKING FOR COVID-19}

The COVID-19 pandemic has disturbed a number of sectors worldwide, including finance, education, production, supply chain, automobiles, agriculture, retail, healthcare, etc. The consequence of the pandemic might be low or high. In order to regain the same situation before the pandemic, policymakers requisite makes sure that the financial sector remains capable of dealing with the public's requirements for financial amenities over digital networks.

\subsection{General Policy Response}

The governments all around the globe facing the challenges of the COVID-19 pandemic had to change and redesign the respective policies while combating the pandemic. It was a common imperative for almost every country of the world to accommodate some changes in the policy matters of various sectors in response to the pandemic to ensure both the safety of the people as well as the smooth running of the various systems. The policy change, intervention and introduction of new policies have, to a large extent, helped to cope up with the challenges imposed on public and private life due to the pandemic.

The policymakers around the globe introduced different policy measures to cope with the recession that happened because of coronavirus and classified them into monetary measures, fiscal measures, public health measures, and human control measures shown in Table 3 (Stiglitz, 2010).

\subsection{Fiscal Policy Measures}

In order to alleviate the negative impact on the economy, fiscal policy measures were taken in some countries, as shown in Table 4.

\subsection{Monitory Policy Measures}

Some central banks followed expansionary financial measures to trigger the economy by tuning the interest rates, as depicted in Tables 5 and 6.

Many central banks approve money supply measures utilizing bond purchase programs or in the form of COVID-19 relief funds as presented to spark the economy, as shown in Table 6. 


\section{Table 3. Some Fast Policy Response during the Global Recession}

\begin{tabular}{|c|c|c|c|}
\hline S.No. & Type & Fast Policy Response Adopted by Policymakers & Countries \\
\hline \multirow[t]{5}{*}{1} & \multirow[t]{5}{*}{$\begin{array}{l}\text { Monetary Policy } \\
\text { Measures }\end{array}$} & $\begin{array}{l}\text { Granting (i) regulatory forbearance Id banks, and (ii) principal or interest } \\
\text { moratorium Io debtors affected by COVID-19 }\end{array}$ & Ireland, China. Nigeria and Italy \\
\hline & & Central banks' provision of Liquidity to financial (bond and equity) markets & Chinn and the US \\
\hline & & $\begin{array}{l}\text { Central banks purchase bonds and securities that were plunging ii) value } \\
\text { rapidly. }\end{array}$ & Australia. EU and Canada \\
\hline & & Lowering interest rates by Central banks & $\begin{array}{l}\text { Turley, the US, New Zealand. Japan and } \\
\text { the UK, Nigeria. South Korea and Canada }\end{array}$ \\
\hline & & $\begin{array}{l}\text { The sustained flow of credit (for banks, SMEs, public health sector, individuals } \\
\text { and essential businesses) }\end{array}$ & Australia, Nigeria, US and UK \\
\hline \multirow[t]{3}{*}{2} & \multirow[t]{3}{*}{ Fiscal measures } & $\begin{array}{l}\text { Governments approving a large federal stimulus package for sectors and } \\
\text { industries most affected by the 00VID-I9 pandemic }\end{array}$ & The UK, ILS, Australia and Nigeria \\
\hline & & Provision of income support for individuals & Australia, the US, the UK and India \\
\hline & & Social welfare payments to support each household & Australia and the US \\
\hline \multirow[t]{4}{*}{3} & \multirow[t]{3}{*}{$\begin{array}{l}\text { Public health } \\
\text { measure }\end{array}$} & Public quarantine & $\begin{array}{l}\text { India, the US, the UK and almost every } \\
\text { country }\end{array}$ \\
\hline & & Border quarantine & $\begin{array}{l}\text { Poland, Vietnam, India, the UK, the US, } \\
\text { Pakistan, Australia and Colombia }\end{array}$ \\
\hline & & Issuing a stay-at-home policy & Italy. Iran. Nigeria and the UK \\
\hline & & Social distancing policy & $\begin{array}{l}\text { South Africa, the US, the UK, UAE, } \\
\text { Singapore. Nigeria. Japan. China. India. } \\
\text { Germany, Pakistan. Australia. South Korea } \\
\text { and Israel }\end{array}$ \\
\hline \multirow[t]{6}{*}{4} & \multirow{4}{*}{$\begin{array}{l}\text { Human control } \\
\text { measures }\end{array}$} & Temporary release of prisoners from overcrowded prisons & Iran and the US. \\
\hline & & The shutdown of air, land and sea bonder; & $\begin{array}{l}\text { Taiwan, India, Mexico, the US. Germany, } \\
\text { Serbia and Nigeria }\end{array}$ \\
\hline & & Shutdown of schools & $\begin{array}{l}\text { The UK, Spain, Italy, South Africa, Nigeria } \\
\text { and the US. }\end{array}$ \\
\hline & & Using the military to enforce a coronavirus stay-at-home lockdown & $\begin{array}{l}\text { Malaysia. Italy. The US. Israel. South } \\
\text { Africa and Spain }\end{array}$ \\
\hline & & Travel ban & $\begin{array}{l}\text { EU, The US, Argentina, Austria, Australia, } \\
\text { Bolivia, Cambodia, Canada, China, Cape } \\
\text { Verde, Cambodia, Colombia, Croatia, } \\
\text { Denmark, Egypt, Germany, Greece and } \\
\text { Haiti }\end{array}$ \\
\hline & & Visa denial and suspension & $\begin{array}{l}\text { South Africa, Canada, Singapore, China, } \\
\text { Nigeria, Ghana, Kenya. Bolivia and Brazil }\end{array}$ \\
\hline \multirow[t]{4}{*}{5} & \multirow{2}{*}{$\begin{array}{l}\text { Digital Business } \\
\text { initiatives }\end{array}$} & Build public databases based on transactions & USA, UK, Russia, China \\
\hline & & Grant of subsidies based on lower interest rates & India,Srilanka,Germany \\
\hline & & Integrating technology in business practices & $\begin{array}{l}\text { India, Pakistan, Bangladesh, Nigeria, } \\
\text { Taiwan, Nepal and Bhutan }\end{array}$ \\
\hline & & Technology-enabled risk assessments & $\begin{array}{l}\text { USA, UK, Russia, China, Italy, Japan } \\
\text { and France }\end{array}$ \\
\hline
\end{tabular}


Table 4. Fiscal Policy Measures to Combat Spread of Coronavirus

\begin{tabular}{|c|c|c|c|c|c|}
\hline Countries & $\begin{array}{l}\text { Total Increase in } \\
\text { Direct Spending }\end{array}$ & $\%$ of GDP & $\begin{array}{l}\text { Fiscal Support via } \\
\text { Loans and Loan } \\
\text { Guarantees }\end{array}$ & $\%$ of GDP & Remarks \\
\hline US & USD $\$ 484$ bn & 2.4 & USD2.3tn & 93 & $\begin{array}{l}\text { Measures } \\
\text { announced }\end{array}$ \\
\hline UK & GBP 3SObn & 11.8 & GBP330bn & 10.7 & $\begin{array}{l}\text { Measures } \\
\text { announced }\end{array}$ \\
\hline Canada & $\mathrm{C} \$ 107 \mathrm{bn}$ & 6.2 & - & - & $\begin{array}{l}\text { Measures } \\
\text { announced }\end{array}$ \\
\hline Czech & CZK 100bn & 1.8 & CZK900bn & 15.9 & $\begin{array}{l}\text { Measures } \\
\text { announced }\end{array}$ \\
\hline Poland & ZL 212bn & 9 & ZL700mn & 0.1 & - \\
\hline Romania & RON 9bn & 0.9 & EUR 400mn & 0.2 & - \\
\hline Russia & RUB 1.4tn & 0.3 & - & - & $\begin{array}{l}\text { Measures } \\
\text { announced }\end{array}$ \\
\hline Egypt & EGP 50bm & 0.8 & EGP50bn & 0.8 & - \\
\hline Israel & ILS $2.8 \mathrm{bn}$ & 0.4 & - & - & \\
\hline $\begin{array}{l}\text { Saudi } \\
\text { Arabia }\end{array}$ & SR 120 billion & 3.9 & - & - & - \\
\hline Turkey & 100 billion LIRA & 185 & - & - & $\begin{array}{l}\text { Increased credit. } \\
\text { Lower taxes } \\
\text { and deferred } \\
\text { payments }\end{array}$ \\
\hline Nigeria & NGN3.5tn & 2.3 & $\$ 6.9 \mathrm{bn}$ & 7.5 & $\begin{array}{l}\text { Measured } \\
\text { announced }\end{array}$ \\
\hline India & INR 1.7 lakh crore & 967 & $\$ 1$ billion & 0.04 & $\begin{array}{l}\text { World hank } \\
\text { Loan }\end{array}$ \\
\hline
\end{tabular}

(Source: Media reports and Central Banks' press release) 
Table 5. Monetary Policy Measures Announced to Mitigate the Negative Economic Impact of COVID-19 in Central \& Eastern Europe, Middle East and African countries.

\begin{tabular}{|c|c|c|c|c|c|c|}
\hline \multirow[t]{2}{*}{ Countries } & \multicolumn{3}{|c|}{ Monetary Policy Rate } & \multirow{2}{*}{$\begin{array}{l}\text { New asset } \\
\text { purchases }\end{array}$} & \multirow{2}{*}{$\begin{array}{l}\text { Credit and } \\
\text { liquidity } \\
\text { facilities }\end{array}$} & \multirow[t]{2}{*}{ Additional } \\
\hline & $\begin{array}{l}\text { As of } \\
1 \text { January }\end{array}$ & $\begin{array}{l}\text { Current } \\
\text { rate }\end{array}$ & $\begin{array}{l}\text { End of 2 } 2^{\text {nd }} \\
\text { Quarter }\end{array}$ & & & \\
\hline Czech & 2.00 & 1.75 & 1.00 & $\begin{array}{l}\text { Government } \\
\text { bonds }\end{array}$ & $\begin{array}{l}\text { Increased } \\
\text { FX swap } \\
\text { stock }\end{array}$ & - \\
\hline Hungary & 0.90 & 0.90 & 0.90 & - & - & $\begin{array}{l}\text { Grace period for Loans extended } \\
\text { to firms under FGS scheme }\end{array}$ \\
\hline Poland & 1.50 & 1.00 & 0.50 & $\begin{array}{l}\text { Government } \\
\text { bonds }\end{array}$ & - & $\begin{array}{l}\text { Decreased reserve requirement } \\
\text { and increased interest rate }\end{array}$ \\
\hline Romania & 2.50 & 2.00 & 1.50 & $\begin{array}{l}\text { Government } \\
\text { bonds }\end{array}$ & - & - \\
\hline Russia & 6.25 & 6.00 & 6.00 & FX sales & - & - \\
\hline Ukraine & 13.50 & 10.00 & 8.50 & FX Sales & - & - \\
\hline Egypt & 12.25 & 9.25 & 9.25 & - & - & $\begin{array}{l}\text { Measures discussed to reduce } \\
\text { the Loan burden on firms and } \\
\text { households }\end{array}$ \\
\hline Israel & 0.25 & 0.25 & 0.10 & $\begin{array}{l}\text { Government } \\
\text { bonds }\end{array}$ & & - \\
\hline $\begin{array}{l}\text { Saudi } \\
\text { Arabia }\end{array}$ & 2.25 & 1.00 & - & - & - & - \\
\hline Turkey & 12.00 & 9.75 & - & - & - & $\begin{array}{l}\text { Wide range of measures such } \\
\text { as new credit facilities, reduced } \\
\text { reserve requirements, etc. }\end{array}$ \\
\hline Ghana & 16.00 & 14.50 & 14.50 & - & - & $\begin{array}{l}\text { Reduced primary reserve } \\
\text { requirement and other ratios to } \\
\text { release Liquidity }\end{array}$ \\
\hline Kenya & 8.50 & 7.25 & - & - & - & $\begin{array}{l}\text { Reduced cash reserve ratio, } \\
\text { extensive loan restructuring }\end{array}$ \\
\hline Nigeria & 13.50 & 13.50 & - & - & - & $\begin{array}{l}\text { Measures towards moving away } \\
\text { from multiple EX regimes, } \\
\text { reduced intervention rate, reducing } \\
\text { the federal interest rate. }\end{array}$ \\
\hline India & 515 & 4.4 & & & $\begin{array}{l}3.74 \text { lakh } \\
\text { crore } \\
\text { liquidity } \\
\text { injected }\end{array}$ & $\begin{array}{l}\text { Reduced CRR to } 3 \% \text {. Three-mu } \\
\text { nth moratorium on term loans } \\
\text { outstanding. Total liquidity } \\
\text { injection } 3.4 \% \text { of GDP }\end{array}$ \\
\hline $\begin{array}{l}\text { South } \\
\text { Africa }\end{array}$ & 6.50 & 5.25 & 4.75 & - & - & - \\
\hline
\end{tabular}

(Source: Goldman Sachs Global Investment Research (exhibit 6)) 
Table 6. Central bank spending

\begin{tabular}{|c|c|c|c|}
\hline S.No. & Central Bank & Amount & Covid-19 Policy response \\
\hline 1 & Reserve Bank of India & $\$ 50$ billion & $\begin{array}{l}\text { India adopted a 'whatever it takes' policy, which } \\
\text { suggests an uncapped spending }\end{array}$ \\
\hline 2 & Central Bank of Russia & 300-billion ruble ( $\$ 4$ billion) & Anti-coronavirus crisis fund \\
\hline 3 & Bank of Canada & $\mathrm{C} \$ 1.0$ billion (US $\$ 703$ million) & $\begin{array}{l}\text { Purchase of government bonds, beginning with the } \\
\text { purchase of } C \$ 5 \text { billion per week }\end{array}$ \\
\hline 4 & ECB & $\begin{array}{l}€ 730 \mathrm{bn}(£ 637 \mathrm{bn}) \\
\text { (\$796.2billion) }\end{array}$ & $\begin{array}{l}\text { An emergency fund for the bond pure base program for } \\
\text { EU member countries }\end{array}$ \\
\hline 5 & Bank of England & $£ 200$ billion pounds ( $\$ 248$ billion) & $\begin{array}{l}\text { The first round of quantitative easing took place. An } \\
\text { additional round of } \mathrm{QE} \text { is currently being considered. }\end{array}$ \\
\hline 6 & Federal reserve & more than $\$ 3$ trillion & $\begin{array}{l}\text { For loans and asset purchases. FED said its balance } \\
\text { sheet had exceeded US } \$ 3 \text { trillion }\end{array}$ \\
\hline 7 & People Bank of China & 500billion yuan ( $\$ 79$ billion) & To rescue a virus-weakened economy \\
\hline 8 & $\begin{array}{l}\text { Reserve Bank of South } \\
\text { Africa }\end{array}$ & - & $\begin{array}{l}\text { Fiscal authorities are taking the lead on this, not the } \\
\text { central bank }\end{array}$ \\
\hline 9 & Bank of France & 45 billion euros ( $\$ 48.9$ billion) & Countries allocation from the ECB rescue fund \\
\hline 10 & Central Bank of Italy & 25 billion euros ( $\$ 27.2$ billion) & Countries allocation from the ECB rescue fund \\
\hline II & Reserve Bank of Australia & $\mathrm{A} \$ 90$ billion ( $\$ 56$ billion) & Coronavirus support fund \\
\hline \multirow[t]{2}{*}{12} & Central Bank of Brazil & 1.2 trillion real ( $\$ 231$ billion $)$ & Financial support to counter the effects of COVID-19 \\
\hline & Total & $\$ 4,541$ trillion & \\
\hline
\end{tabular}

\section{CONCLUSION}

In the past, the world had faced several pandemics that either affected a particular country or a region, same as in 2020, most of the population agreed that coronavirus could be treated and controlled in a limited period. But as time passed, this deadly disease seemed to be in full swing and engulfed the whole world within no time. As in the early stage of recession during COVID-19, it was assumed that the impact of the recession would be localized and the financial crisis would be comparatively a negligible point of issue only affecting the US, but in the end, its impact was seen over the global financial system. The unexpected interruption in the economy due to the COVID-19 pandemic is destructive and an alarming concern to first-order supply and demand shocks throughout the world. Pandemics come, they spread destruction, mortality, loss and pain, but humanity always fights back and overcomes all the difficulties and challenges. This COVID19 pandemic has taught everyone how to fight difficult times together as the human race with efficient uses of technology and resources available. Undoubtedly, our mishandling of dangers still surround us, and they still need consensus, wisdom, and generosity. This world needs leaders who can guide us and take responsibility during new emerging challenges. This world awaits a new generation of responsible citizens willing to make this planet the most beautiful place in the universe.

\section{ACKNOWLEDGMENT}

This research work was catalyzed and supported by the National Council for Science and Technology Communications (NCSTC), Department of Science and Technology (DST), Ministry of Science and Technology (Govt. of India), New Delhi, India [grant recipient: Dr. Harleen Kaur and grant No. 5753/ IFD/ 2015-16]. This work is supported by VC Research (VCR 0000110) for Prof. Chang.

Professor Victor Chang, affiliated with Tesside University in Middlesbrough, England, aided with the supervision and completion of this research work as corresponding author. 


\section{REFERENCES}

Allen, F., \& Carletti, E. (2010). An overview of the crisis: Causes, consequences, and solutions. International Review of Finance, 10(1), 1-26. doi:10.1111/j.1468-2443.2009.01103.x

Bagliano, F. C., \& Morana, C. (2012). The Great Recession: US dynamics and spillovers to the world economy. Journal of Banking \& Finance, 36(1), 1-13. doi:10.1016/j.jbankfin.2011.06.002

Bentolila, S., Jansen, M., \& Jiménez, G. (2018). When credit dries up: Job losses in the great recession. Journal of the European Economic Association, 16(3), 650-695. doi:10.1093/jeea/jvx021

Bezemer, D. J. (2011). The credit crisis and recession as a paradigm test. Journal of Economic Issues, 45(1), 1-18. doi:10.2753/JEI0021-3624450101

Burki, T. K. (2020). Coronavirus in China. The Lancet. Respiratory Medicine, 8(3), 238.

Chen, N., Zhou, M., Dong, X., Qu, J., Gong, F., Han, Y., \& Yu, T. (2020). Epidemiological and clinical characteristics of 99 cases of 2019 novel coronavirus pneumonia in Wuhan, China: A descriptive study. Lancet, 395(10223), 507-513.

Coronavirus Disease 2019 in Children-United States. (2020). Morbidity and Mortality Weekly Report, 69(14), 422-426.

El-Erian, M. A. (2020). The Coming Coronavirus Recession and the Uncharted Territory Beyond. Foreign Affairs, 27. https://www.foreignaffairs.com/articles/2020-03-

Gaiotti, E. (2013). Credit availability and investment: Lessons from the "great recession". European Economic Review, 59, 212-227. doi:10.1016/j.euroecorev.2012.12.007

García-Vidal, G., Guzmán-Vilar, L., Sánchez-Rodríguez, A., Martínez-Vivar, R., Pérez-Campdesuñer, R., \& Uset-Ruiz, F. (2020). Facing post COVID-19 era, what is really important for Ecuadorian SMEs? International Journal of Engineering Business Management. doi:10.1177/1847979020971944

Gorbalenya, A. E., Baker, S. C., Baric, R. S., de Groot, R. J., Drosten, C., \& Gulyaeva, A. A. (2020). Severe acute respiratory syndrome-related coronavirus: The species and its viruses-a statement of the Coronavirus Study Group. bioRxiv, 937862.

Harapan, H., Itoh, N., Yufika, A., Winardi, W., Keam, S., Te, H., \&Mudatsir, M. (2020). Coronavirus disease 2019 (COVID-19): A literature review. Journal of Infection and Public Health.

Horowit, J. (2020). The global coronavirus recession is beginning. CNN. Media report. https://edition.cnn. com/2020/03/16/economy/global-recession-coronavirus/index.html

Huang, C., Wang, Y., Li, X., Ren, L., Zhao, J., Hu, Y., \& Cheng, Z. (2020). Clinical features of patients infected with 2019 novel coronavirus in Wuhan, China. Lancet, 395(10223), 497-506.

Hui, D. S., Azhar, E. I., Madani, T. A., Ntoumi, F., Kock, R., Dar, O., \& Zumla, A. et al. (2020). The continuing 2019-nCoV epidemic threat of novel coronaviruses to global health-The latest 2019 novel coronavirus outbreak in Wuhan, China. International Journal of Infectious Diseases, 91, 264-266. doi:10.1016/j.ijid.2020.01.009 PMID:31953166

Jagannathan, R., Kapoor, M., \& Schaumburg, E. (2013). Causes of the great recession of 2007-2009: The financial crisis was the symptom not the disease! Journal of Financial Intermediation, 22(1), 4-29. doi:10.1016/j. jfi.2012.06.002

Lechman, E., \& Kaur, H. (2016). Social Development and ICT Adoption. Developing World Perspective. Economia e Sociologia, 9(2).

Lu, H., Stratton, C. W., \& Tang, Y. W. (2020). Outbreak of pneumonia of unknown etiology in Wuhan, China: The mystery and the miracle. Journal of Medical Virology, 92(4), 401-402. doi:10.1002/jmv.25678 PMID:31950516

Marszk, A., Lechman, E., \& Kaur, H. (2017). Financial markets diffusion patterns.The case of Mexican investment funds. Equilibrium. Quarterly Journal of Economics and Economic Policy, 12(1), 83-100. 
Mian, A., \& Sufi, A. (2010). The great recession: Lessons from microeconomic data. The American Economic Review, 100(2), 51-56. doi:10.1257/aer.100.2.51

Qiu, J., Shen, B., Zhao, M., Wang, Z., Xie, B., \& Xu, Y. (2020). A nationwide survey of psychological distress among Chinese people in the COVID-19 epidemic: Implications and policy recommendations. General Psychiatry, 33, e100213. doi:10.1136/gpsych-2020-100213

Radelet, S., Sachs, J. D., Cooper, R. N., \& Bosworth, B. P. (1998). The East Asian financial crisis: Diagnosis, remedies, prospects. Brookings Papers on Economic Activity, 1998(1), 1-90. doi:10.2307/2534670

Sato, Y., Tse, Y. K., \& Tan, K. H. (2020). Managers' risk perception of supply chain uncertainties. Industrial Management \& Data Systems, 120(9), 1617-1634. https://doi.org/10.1108/IMDS-01-2020-0049

Stiglitz, J. E. (2010). Interpreting the Causes of the Great Recession of 2008. In Financial system and macroeconomic resilience: Revisited. Bank for International Settlements.

World Health Organization. (2020). Coronavirus disease 2019 (COVID-19): situation report, 30. WHO.

Bhavya Alankar, Ph.D. (CSE), M.Tech. (CSE), Fellow (IETE), is currently working as a senior faculty at Department of Computer Science and Engg. at Jamia Hamdard, New Delhi, India. Previously employed at National Institute of Technology (NIT), Jalandhar, India. He has done his Ph.D. in Reconfigurable Computing from Uttarakhand Technical University, India and Masters in Technology in VLSI design from CDAC, Mohali, India and. He has 15 years of teaching and research experience. His research interests are in VLSI design, Cloud computing, Deep learning, Reconfigurable computing. He is author and editor to books in the area on VLSI, Machine Learning and IOT. He has received many awards and recognition from international bodies.

Shafqatul Ahsaan is an IT graduate from University of Kashmir. They did their masters in computer science from Jamia Hamdard university, New Delhi. Their research interests are Big Data Analytics, Machine Learning and Data Mining.

Gaurav Sharma is a Project Associate who works with the Central Institute of Educational Technology, NCERT. He has 4 years of experience in the Cloud Administrator. He is currently enrolled as a third-year student of M. Tech Computer Science Part-time, Department of Computer Science at Jamia Hamdard. He post-graduated from Maharishi Dayanand University with a Master of Computer Application and graduated from the University of Delhi with a Bachelor's Degree in Computer Science (Hons). He received the technical certificate from RedHat, Microsoft, and AWS. Gaurav Sharma currently lives in Delhi, India, and He enjoys cooking.

Victor Chang $(P h D)$ is a Professor of Data Science and IS at Teesside University, UK. He was a Senior Associate Professor, Xi'an Jiaotong-Liverpool University between June 2016 and Aug 2019. He was a Senior Lecturer at Leeds Beckett University, UK between Sep 2012 and May 2016. Within 4 years, he completed Ph.D. (CS, Southampton) and PGCert (HE, Fellow, Greenwich) while working for several projects. Before becoming an academic, he achieved $97 \%$ on average in 27 IT certifications. He won an IEEE Outstanding Service Award in 2015, best papers in 2012, 2015 \& 2018, 2016 European award: Best Project in Research, 2017 Outstanding Young Scientist and numerous awards since 2012. He is widely regarded as a leading expert on Big Data/Cloud/loT/security. He is a visiting scholar/PhD examiner at several universities, an Editor-in-Chief of IJOCI \& OJBD, former Editor of FGCS, Associate Editor of TII \& Info Fusion, founding chair of international workshops and founding Conference Chair of IOTBDS, COMPLEXIS, FEMIB \& IIOTBDSC. He was involved in projects worth more than £13 million in Europe and Asia. He published 3 books and edited 2 books. He gave 18 keynotes internationally as a top researcher. 